\title{
Stability of lipids during wet storage of the marine diatom Porosira glacialis under semi-preserved conditions at 4 and $20^{\circ} \mathrm{C}$
}

\author{
Lars Dalheim $^{1}\left(\mathbb{D} \cdot\right.$ Jon B. Svenning ${ }^{1} \cdot$ Hans C. Eilertsen ${ }^{1} \cdot$ Terje Vasskog $^{2} \cdot$ Ragnar L. Olsen $^{1}$
}

Received: 2 July 2020 / Revised and accepted: 30 September 2020 / Published online: 17 October 2020

(C) The Author(s) 2020

\begin{abstract}
Cultivation of diatoms may help alleviate the pressure on wild fish stocks for marine nutrient availability in aquaculture feed and for human consumption. However, the lipids in microalgae biomass are easily deteriorated, both trough lipolysis and degradation of polyunsaturated fatty acids (PUFA). Proper storage conditions are therefore necessary to maintain the lipid quality. Additionally, the storage conditions must have a low cost and facilitate further processing of the biomass. In this study, we investigated the formation of free fatty acids, changes in lipid classes, and fatty acid composition of the psychrophilic marine diatom Porosira glacialis under storage. The wet biomass was stored for 14 days at 4 and $20^{\circ} \mathrm{C}$ with either heat treatment, formic acid, or benzoic acid addition, and a control sample. Heat-treated and formic acid samples had the lowest rate of free fatty acid formation during storage. Mainly, polar lipids were hydrolyzed to free fatty acids and this occurred fastest at $20^{\circ} \mathrm{C}$. The fatty acid composition remained stable in heat-treated samples during storage, whereas a loss of PUFA was observed in the other treatments. The lack of effect from benzoic acid indicates that the loss of lipid quality stems from endogenous enzymes rather than exogenous organisms. Heat treatment and formic acid appeared to effectively reduce lipase activity, and potentially lipoxygenase and similar enzymes that affect the fatty acids. The low $\mathrm{pH}$ of the formic acid samples seems to have a negative effect on the PUFA content, in particular at $20^{\circ} \mathrm{C}$.
\end{abstract}

Keywords Storage stability $\cdot$ Lipid $\cdot$ Omega-3 $\cdot$ Pre-treatment $\cdot$ Psychrophilic diatom $\cdot$ Microalgae

\section{Introduction}

The limit for sustainable utilization of wild fish stocks has been reached (FAO 2020), and there is a need for novel

Lars Dalheim

lars.dalheim@uit.no

Jon B. Svenning

jon.b.svenning@uit.no

Hans C. Eilertsen

hans.c.eilertsen@uit.no

Terje Vasskog

terje.vasskog@uit.no

Ragnar L. Olsen

ragnar.olsen@uit.no

1 Norwegian College of Fishery Science, UiT The Arctic University of Norway, N-9037 Tromsø, Norway

2 Department of Pharmacy, UiT The Arctic University of Norway, N-9037 Tromsø, Norway sources of marine nutritional components, especially the long-chain polyunsaturated omega- 3 fatty acids (LC-PUFA $\mathrm{n}-3)$. Marine microalgae are the main de novo producers of the LC-PUFA n-3, eicosapentaenoic acid (EPA, 20:5n-3), and docosahexaenoic acid (DHA, 22:6n-3) (Khozin-Goldberg et al. 2011), which are important components in aquaculture feed (Tocher 2015; Sprague et al. 2016) and for human health (Kris-Etherton et al. 2009; Salem and Eggersdorfer 2015). In addition to omega-3 fatty acids, marine microalgae contain valuable pigments and other bioactive compounds (CuellarBermudez et al. 2015; Kuczynska et al. 2015). Diatoms, the largest group of microalgae, have potentially high growth rates and can be cultivated in bioreactors using seawater, light, inorganic nutrients, and $\mathrm{CO}_{2}$ at a wide range of temperatures (Artamonova et al. 2017b; Botte et al. 2018; Svenning et al. 2019). Large-scale industrial production of microalgae biomass could help alleviate the pressure on wild fish stocks by substituting some of the fishmeal and fish oil in the aquaculture feed (Shah et al. 2018) and also be used to produce health supplements for humans (Barkia et al. 2019).

One of the main challenges of large-scale utilization of diatoms is post-harvest storage. The diatom fatty acids are 
often highly unsaturated (Dunstan et al. 1994; Chen 2012; Svenning et al. 2019), which makes them prone to oxidation. In addition, endogenous enzymes in the biomass may deteriorate the lipids through lipolysis and oxidation (Fontana et al. 2007; Cutignano et al. 2011). The antigrazer defense mechanism of diatoms, which is woundactivated, involves breaking down thylakoid lipids to produce volatile polyunsaturated aldehydes and other oxylipins (Pohnert 2002; Cutignano et al. 2006; Caldwell 2009). Cell rupture, which can occur during harvesting or because of autolytic reactions during storage, may initiate these processes. Another consequence of cell rupture is the formation of exudates, which may act as a growth medium for other microorganisms such as bacteria and fungi. Optimizing storage conditions are therefore essential for large-scale utilization of microalgae.

The storage conditions must be cost-effective for the microalgae to be a viable replacement for fish products in aquaculture feed. Large-scale freezing facilities are expensive and freezing and thawing the biomass for further processing may pose a challenge due to cell lysis. Pretreatment of the biomass before storage in refrigerated rooms may be a more feasible solution to the storage problem. However, pre-treatments such as drying are costly (Hosseinizand et al. 2017; Wendt et al. 2019), and evaluation of cheaper alternatives are therefore important. Inhibition of enzyme activity could be a potential solution for storage of microalgae biomass. Cheap ways of denaturing and inhibiting enzymes are heat treatment or lowering of $\mathrm{pH}$ by adding an acid (Budge and Parrish 1999; Seyhan et al. 2002). Previous studies have found reduction in lipase activity by adding boiling water directly to the biomass (Berge et al. 1995; Budge and Parrish 1999) or by heating sample tubes in a water bath (Balduyck et al. 2019). Organic acids, such as formic acid and benzoic acid, may also inhibit bacterial and fungal growth (Heasman et al. 2000; Olsen and Toppe 2017; Cabezas-Pizarro et al. 2018).

In this study, the large centric psychrophilic diatom Porosira glacialis was cultivated using $\mathrm{CO}_{2}$-containing flue gas from an industrial plant. The fatty acid profile of this diatom is highly unsaturated (Svenning et al. 2019) and could therefore be a valuable source of marine fatty acids for aquaculture feed and human consumption. The goal of this study was to investigate the best storage conditions, applicable for industrial use, to reduce lipid deterioration. The pre-treatments with formic acid (enzyme inhibiting and antimicrobial), benzoic acid (antimicrobial), and heat treatment (denaturing of endogenous enzymes) was compared with control samples without pre-treatment during storage for 14 days at 4 and $20^{\circ} \mathrm{C}$. The lipid quality was assessed in terms of lipolysis, lipid class, and fatty acid composition.

\section{Materials and methods}

\section{Materials}

Dichloromethane (DCM) ( $\geq 99.9 \%)$, hexane $(\geq 99 \%)$, sulfuric acid (95-97\%) were from Sigma-Aldrich (USA). LC-MS grade methanol (MeOH) was from Fisher Scientific (UK). Acetic acid $(\geq 99.8 \%)$ was from Honeywell Fluka (USA). Sodium bicarbonate, sodium acetate, isooctane (LC-grade), ethyl acetate (LC-grade), acetone (LC-grade), and isopropanol (LC-grade) were obtained from Merck (Germany). Kristalon Flower ${ }^{\circledR}$ was obtained from Yara (Oslo, Norway). Sodium metasilicate pentahydrate was obtained from Permakem A/S (Norway).

Lipid standards for HPLC analysis DGTS (1,2-dipalmitoylsn-glycero-3-O-4'-(N,N,N-trimethyl)-homoserine), SQDG (sulfoquinovosyldiacylglycerol), and phosphatidylinositol were purchased from Sigma Aldrich. Phosphatidylcholine (PC; 1,2dimyristoyl-sn-glycero-3-phosphatidylcholine), phosphatidylglycerol (PG; 1,2-dimyristoyl-sn-glycero-3phosphatidylglycerol Na salt), phosphatidylserine (PS; 1,2dipalmitoyl-sn-glycero-3-phosphatidylserine Na salt), phosphatidylethanolamine (PE; 1,2-dimyristoyl-sn-glycero-3-phosphatidylethanolamine), MGDG (hydrogenated monogalactosyldiacylglycerol), DGDG (hydrogenated digalactosyldiacylglycerol), ergosterol, triolein, diolein, and monoolein were purchased from Larodan AB. Ethyl elaidate, 11-eicosenol, and behenyl arachidate were purchased from $\mathrm{Nu}-$ Chek-Prep, Inc. Standards for the GC analysis, GLC-502 as free acids, were purchased from Nu-Chek-Prep, Inc.

\section{Cultivation of Porosira glacialis}

Biomass was harvested from a continuous culture maintained in the exponential growth phase on two occasions to obtain sufficient material for the experimental procedure. Briefly, the monocultures were cultivated in a 6000-L fiberglass vertical column photobioreactor using seawater collected at $25 \mathrm{~m}$ depth in the Indre Finnfjordbotn water reservoir. The water was filtered using $1 \mu \mathrm{m}$ polypropylene filters (Model GX01-9 $7 / 8$, GE Power \& Water, USA) and added inorganic nutrients in the form of $0.25 \mathrm{~mL} \mathrm{~L}^{-1}$ Substral and $1 \mathrm{~mL} \mathrm{~L}^{-1}$ dissolved silicate ( $3.5 \mathrm{~g} \mathrm{Na}_{2} \mathrm{O}_{3} \mathrm{Si}_{1} 9 \mathrm{H}_{2} \mathrm{O} \mathrm{L}^{-1}$ in miliQ water). The strain of $P$. glacialis used in this experiment was isolated from arctic waters and identified using SEM (Uradnikova 2020). The reactor, placed outdoors, was subjected to the natural environment of Finnfjordbotn (N 69 $13.76^{\prime}$, E $018^{\circ} 05.02^{\prime}$ ), but illuminated with continuous artificial light (LED) at a scalar irradiance of $150-200 \mu \mathrm{mol}$ quanta $\mathrm{m}^{-2} \mathrm{~s}^{-1}$. The culture was aerated with either pressurized air or flue gas containing 6$12 \% \mathrm{CO}_{2}$, and maintained at $\mathrm{pH}$ 7.4-8.1. Temperature varied between 4 and $8{ }^{\circ} \mathrm{C}$ during the entire cultivation, reflecting the ambient seawater temperatures at Finnfjordbotn. The culture condition was monitored on a daily basis by cell counts in 
$2 \mathrm{~mL}$ Nunc-chambers (Nunc A/S, Denmark) and harvested when the density of the culture reached approximately 15 million cells $\mathrm{L}^{-1}$. The harvesting was performed using a continuous solid bowl centrifuge (Model PTDC, Nanjing Kingreat Machinery Company, Jiangsu, China) operated at $835 \times g$, the resulting biomass was collected using a spatula.

\section{Storage conditions}

Samples with 20\% DM were given different pretreatments; a batch of microalgae biomass was added $0.1 \%$ benzoic acid ( $\mathrm{pH}$ 6.9) and divided into 24 samples, another batch of microalgal biomass were added formic acid to a $\mathrm{pH}$ of 3.0 and divided into 24 samples; 24 samples were heated to $70{ }^{\circ} \mathrm{C}$ for $30 \mathrm{~min}$ and 24 samples were untreated (control). Triplicates of the samples were stored in capped $15 \mathrm{~mL}$ centrifuge tubes (VWR International, USA) at 4 and $20^{\circ} \mathrm{C}$ for 1 , 3,7 , and 14 days before lipid extraction and analysis.

In a follow-up study, higher temperature pre-treatments were investigated to see how it would affect lipolysis in the samples during storage. Frozen biomass was divided into $15 \mathrm{~mL}$ centrifuge tubes and heated for $30 \mathrm{~min}$ at 70,80 , or $90^{\circ} \mathrm{C}$. The samples were stored in triplicates for 7 and 14 days at $20^{\circ} \mathrm{C}$ along with triplicates of untreated control samples.

\section{Lipid extraction and analysis}

The extraction procedure was adapted from Folch et al. (1957), using a mixture of dichloromethane and methanol as the solvent (Cequier-Sanchez et al. 2008). Briefly, samples were freeze-dried and divided into triplicates of $100 \mathrm{mg}$ in $15 \mathrm{~mL}$ centrifuge tubes. Each tube was added $2 \mathrm{~mL}$ dichloromethane/methanol $(2: 1 \mathrm{v} / \mathrm{v})$ and $2 \mathrm{~mL} 5 \% \mathrm{NaCl}$ in MiliQ water. The tubes were gently shaken for $30 \mathrm{~s}$ by hand and then centrifuged for $10 \mathrm{~min}$ at $2000 \times \mathrm{g}$ (Heraus Multifuge 1S-R, Germany). Following centrifugation, the organic phase was transferred to a pre-weighed vial. The extraction procedure was repeated twice and the organic phases were pooled before evaporation using nitrogen. Finally, the extracted lipids were dissolved in dichloromethane/methanol $(2: 1 \mathrm{v} / \mathrm{v})$ to a concentration of $10 \mathrm{mg} \mathrm{mL}^{-1}$, before methanolysis and methylation using a method adapted from Stoffel et al. (1959) with sulfuric acid as the catalyst. Dissolved extract $(100 \mu \mathrm{L})$ was transferred to a test tube (Duran, Millville, USA) along with $100 \mu \mathrm{L}$ internal standard $\left(0.1 \mathrm{mg} \mathrm{mL}^{-1}\right)$ and $800 \mu \mathrm{L}$ dichloromethane. The samples were then added $2 \mathrm{~mL} 10 \% \mathrm{H}_{2} \mathrm{SO}_{4}$ in methanol and placed at $100{ }^{\circ} \mathrm{C}$ for $1 \mathrm{~h}$. Finally, $3 \mathrm{~mL}$ hexane and $3 \mathrm{~mL} 5 \% \mathrm{NaCl}$ in MiliQ water were added and the samples were shaken. The resulting organic phase containing the fatty acid methyl esters (FAMEs) was evaporated and dissolved in $100 \mu \mathrm{L}$ hexane before GC-FID analysis.
The GC conditions were as follows: helium as carrier gas $\left(1.6 \mathrm{~mL} \mathrm{~min}^{-1}\right.$ ), select FAME column (L $50 \mathrm{~m}$, ID $0.25 \mathrm{~mm}$, and FT $0.25 \mu \mathrm{m}$, Agilent J\&W GC Columns), the inlet temperature was $240{ }^{\circ} \mathrm{C}$ (split 1:50), and the FID temperature was $250{ }^{\circ} \mathrm{C}$. Initially, the $\mathrm{GC}$ oven was held at $60{ }^{\circ} \mathrm{C}$ for $1 \mathrm{~min}$, then ramped up to $130{ }^{\circ} \mathrm{C}\left(30^{\circ} \mathrm{C} \mathrm{min}^{-1}\right)$, further up to $195^{\circ} \mathrm{C}$ $\left(1.3{ }^{\circ} \mathrm{C} \mathrm{min}^{-1}\right)$ and finally up to $240{ }^{\circ} \mathrm{C}\left(30^{\circ} \mathrm{C} \mathrm{min}^{-1}\right)$ for $10 \mathrm{~min}$. To quantify the fatty acids, calibration curves were made by analyzing the ratio between individual fatty acids at concentrations $7.8125-2000 \mu \mathrm{g} \mathrm{mL}^{-1}$ of GLC 502 free acids (Nu-Chek-Prep, USA) and heptadecanoic acid (SigmaAldrich, USA) as internal standard; every concentration was analyzed as triplicates.

Free fatty acids and other lipid classes were separated and quantified using HPLC-ELSD based on a method by Abreu et al. (2017). HPLC analyses were performed on a Waters e2795 separations module, using a SupelcosilLCSI $5 \mu \mathrm{m}(25 \mathrm{~cm} \times 4.6 \mathrm{~mm})$ column (Supelco, USA) set to a working temperature of $40^{\circ} \mathrm{C}$ and $40 \mu \mathrm{L}$ injection volume. The lipids were quantified using a Waters 2424 ELS detector with the following settings: gain 100, nebulizer $30 \%$ heating power level, drift tube $45^{\circ} \mathrm{C}$, and pressure 40 psi. The total run time was $41 \mathrm{~min}$ and the gradient profile can be seen in Table 1. Standard curves were made by analyzing $12.5-400 \mu \mathrm{g} \mathrm{mL}^{-1}$ of the lipid classes in triplicates. Both samples and standards were dissolved in mobile phase A/chloroform (4:1).

Table 1 Gradient profile for the HPLC program used for lipid class analysis. Mobile phase A = isooctane/ethyl acetate (99.8:0.2), mobile phase $\mathrm{B}=$ acetone/ethyl acetate $(2: 1) 0.15 \%$ acetic acid, and mobile phase $\mathrm{C}=$ isopropanol $/ \mathrm{H}_{2} \mathrm{O}(85: 15)$

\begin{tabular}{llllll}
\hline Time (min) & $\begin{array}{l}\text { Mobile } \\
\text { phase A }\end{array}$ & $\begin{array}{l}\text { Mobile } \\
\text { phase B }\end{array}$ & $\begin{array}{l}\text { Mobile } \\
\text { phase C }\end{array}$ & $\begin{array}{l}\text { Flow } \\
(\mathrm{mL} / \mathrm{min})\end{array}$ & Curve \\
\hline 0.0 & 100 & 0 & 0 & 1.5 & 1 \\
1.5 & 100 & 0 & 0 & 1.5 & 6 \\
1.6 & 97 & 3 & 0 & 1.5 & 6 \\
6.0 & 94 & 6 & 0 & 1.5 & 6 \\
8.0 & 50 & 50 & 0 & 1.5 & 6 \\
8.1 & 46 & 39 & 15 & 1.5 & 6 \\
14.0 & 43 & 30 & 27 & 1.5 & 6 \\
14.1 & 43 & 30 & 27 & 1.5 & 6 \\
18.0 & 40 & 0 & 60 & 1.5 & 6 \\
23.0 & 40 & 0 & 60 & 1.5 & 6 \\
24.0 & 0 & 100 & 0 & 1.5 & 6 \\
25.0 & 0 & 100 & 0 & 2.0 & 6 \\
27.0 & 0 & 100 & 0 & 2.0 & 6 \\
27.1 & 100 & 0 & 0 & 2.0 & 6 \\
36.0 & 100 & 0 & 0 & 2.0 & 6 \\
36.1 & 100 & 0 & 0 & 1.5 & 6 \\
\hline
\end{tabular}




\section{Statistical analysis and data availability}

All analyses were performed in triplicates. The data in tables are presented as means \pm standard deviation. All analyses and figures were prepared using R v3.6.1. Means were considered statistically significant if $P<0.05$ using the pairwise Tukey test. All data and the $\mathrm{R}$ markdown for this experiment are available from the Open Science Framework (OSF (https:// osf.io/6nu9t/?view_only=a6a240b97c3c4d518a2e 2222de901772)) under the name "Stability of lipids during wet storage of the marine diatom Porosira glacialis under semi-preserved conditions at 4 and $20{ }^{\circ} \mathrm{C}$." Supplementary data containing heat maps of statistical test results can be found in the supplementary data folder using the OSF link. All changes within and differences between treatments presented in the text part of the "Results" section are statistically significant $(P<0.05)$.

\section{Results}

The lipid yield for each sample varied between 6.4 and $8.8 \%$ of dry weight (DW), see Table 2. There was no trend for loss of lipids during storage.

Figure 1 shows the evolution of formation of free fatty acids (FFA) content over time; day 1 represents $24 \mathrm{~h}$ of storage. At $4{ }^{\circ} \mathrm{C}$ day 1 , the control samples contained $31 \%$ FFA, which increased to $66 \%$ after 14 days of storage. In the benzoic acid samples, the amount increased from 29 to $65 \%$ in the same time span at $4{ }^{\circ} \mathrm{C}$. The formic acid and the heattreated samples at $4{ }^{\circ} \mathrm{C}$ had the lowest relative amount of FFA at day 1 with 14 and $16 \%$, which increased to $35 \%$ in formic acid samples after 14 days. After $24 \mathrm{~h}$ of storage at $20^{\circ} \mathrm{C}$, the control and benzoic acid samples contained as much as 70 and $65 \%$ FFA, which after 2 weeks increased to 79 and $81 \%$, respectively. The FFA of the formic acid treated samples at $20{ }^{\circ} \mathrm{C}$ increased from 26 at day 1 to $53 \%$ after 14 days. The corresponding values in the heat-treated samples were 12 and $60 \%$. In a separate experiment, $P$. glacialis biomass was heated to 70,80 , or $90{ }^{\circ} \mathrm{C}$ for 30 min (Table 3). The control samples contained $7 \% \mathrm{FFA}$ at day 0 , which increased to $84 \%$ after 7 days of storage at $20{ }^{\circ} \mathrm{C}$. After storage at $20{ }^{\circ} \mathrm{C}$ for 7 days, the FFA content was $68 \%$ in lipids extracted from samples heated to 70 and $80{ }^{\circ} \mathrm{C}$. The samples heated to $90{ }^{\circ} \mathrm{C}$ contained 25 and $40 \%$ FFA after 7 and 14 days of storage at $20^{\circ} \mathrm{C}$, respectively.

The lipid class composition for each time point and treatment is presented in Table 4 to study which lipid class was more prone to lipolysis (day 1 represents $24 \mathrm{~h}$ of storage). The polar lipid classes appear to be the main origin of the free fatty acids formed during storage. The control and the benzoic acid samples at $4{ }^{\circ} \mathrm{C}$ contained 28 and $31 \%$ MGDG after 1 day of storage, and this decreased to 4 and $5 \%$ after 14 days, respectively. The same two samples stored at $20^{\circ} \mathrm{C}$ had a MGDG content of only 2 and $3 \%$ after 1 day of storage and was depleted at day 3 for the control and day 7 for the benzoic acid samples. The formic acid samples contained 25 and $22 \%$ MGDG after 1 day of storage at 4 and $20^{\circ} \mathrm{C}$, respectively. After 14 days of storage, these values had decreased to 11 and $4 \%$. The amount of MGDG in heat-treated samples decreased from 30 to $10 \%$ at $20^{\circ} \mathrm{C}$ during 14 days of storage. In both the control and the benzoic acid samples at $4{ }^{\circ} \mathrm{C}, \mathrm{PG}$ decreased from 25 to $10 \%$ from day 1 to 14 . Similarly, for the same samples at $20{ }^{\circ} \mathrm{C}$, PG was reduced from 12 and $11 \%$ to depletion in both samples after 7 days of storage. Heat-treated samples contained $44 \%$ PG at $4{ }^{\circ} \mathrm{C}$ after 1 day of storage, which decreased to $40 \%$ after 14 days. At $20^{\circ} \mathrm{C}$, the content of PG changed from $38 \%$ to zero from day 1 to day 14 . The amount of PG was lower in the formic acid samples compared with the other treatments. In formic acid samples, the amount of PG decreased from 4 to $1 \%$ during storage at $4{ }^{\circ} \mathrm{C}$ and from 3 to $0 \%$ at $20{ }^{\circ} \mathrm{C}$.

PC was only detected in samples treated with formic acid. The content of PC at day 1 was $10 \%$, which decreased to $6 \%$ during storage at $4{ }^{\circ} \mathrm{C}$. At $20^{\circ} \mathrm{C}, 4 \%$ PC was detected at day 1 with no change during the storage. Additionally, the amount of diacylglycerol (DAG) was much higher in the formic acid samples than the rest.

Table 2 Lipid yield (weight percentage) from day 1 to 14 for both temperatures (mean \pm standard deviation, $n=3$ ). Control samples had no pretreatment, $0.1 \%(\mathrm{w} / \mathrm{w})$ benzoic acid, formic acid to $\mathrm{pH} 3.0$, and heat treatment $70{ }^{\circ} \mathrm{C}$ for $30 \mathrm{~min}$

$$
\text { Lipid yield (\%) }
$$

\begin{tabular}{|c|c|c|c|c|c|c|c|c|}
\hline Temperature $\left({ }^{\circ} \mathrm{C}\right)$ & 4 & & & & 20 & & & \\
\hline Days of storage & 1 & 3 & 7 & 14 & 1 & 3 & 7 & 14 \\
\hline Control & $8.6 \pm 1.4^{\mathrm{a}}$ & $6.9 \pm 0.5^{\mathrm{a}}$ & $7.6 \pm 0.9^{\mathrm{a}}$ & $6.6 \pm 0.6^{\mathrm{a}}$ & $7.4 \pm 1.5^{\mathrm{ab}}$ & $7.4 \pm 0.2^{\mathrm{a}}$ & $7.0 \pm 0.9^{\mathrm{a}}$ & $6.9 \pm 0.7^{\mathrm{ab}}$ \\
\hline Benzoic acid & $7.7 \pm 0.2^{\mathrm{a}}$ & $8.3 \pm 1.2^{\mathrm{ab}}$ & $8.8 \pm 2.0^{\mathrm{a}}$ & $7.0 \pm 0.4^{\mathrm{a}}$ & $7.6 \pm 0.8^{\mathrm{ab}}$ & $7.3 \pm 0.1^{\mathrm{a}}$ & $7.0 \pm 0.3^{\mathrm{a}}$ & $8.0 \pm 0.3^{\mathrm{ab}}$ \\
\hline Formic acid & $7.5 \pm 0.6^{\mathrm{a}}$ & $7.5 \pm 0.0^{\mathrm{ab}}$ & $7.1 \pm 0.3^{\mathrm{a}}$ & $7.1 \pm 0.4^{\mathrm{a}}$ & $6.4 \pm 0.3^{\mathrm{a}}$ & $7.1 \pm 0.1^{\mathrm{a}}$ & $7.4 \pm 0.2^{\mathrm{a}}$ & $6.9 \pm 0.4^{\mathrm{a}}$ \\
\hline Heat treatment & $8.2 \pm 0.7^{\mathrm{a}}$ & $8.7 \pm 0.5^{\mathrm{b}}$ & $8.1 \pm 0.6^{\mathrm{a}}$ & $8.8 \pm 0.5^{\mathrm{b}}$ & $8.5 \pm 0.3^{\mathrm{b}}$ & $7.6 \pm 0.8^{\mathrm{a}}$ & $8.8 \pm 0.9^{\mathrm{a}}$ & $8.1 \pm 0.7^{\mathrm{b}}$ \\
\hline
\end{tabular}

${ }^{\mathrm{a}, \mathrm{b}}$ Results in the same column sharing superscripted letters are not significantly different $(P \geq 0.05)$ 
Fig. 1 Development of lipolysis (Free fatty acid (FFA) content, weight percentage) from day 1 to 14 for each treatment $(n=3)$ at 4 (A) and $20{ }^{\circ} \mathrm{C}(\mathrm{B})$. Benzoic acid $(0.1 \%(\mathrm{w} / \mathrm{w})$, square), control (no pre-treatment, circle), formic acid (pH 3.0, triangle), and heat treatment $\left(70{ }^{\circ} \mathrm{C}\right.$ for $30 \mathrm{~min}$, diamond $)$

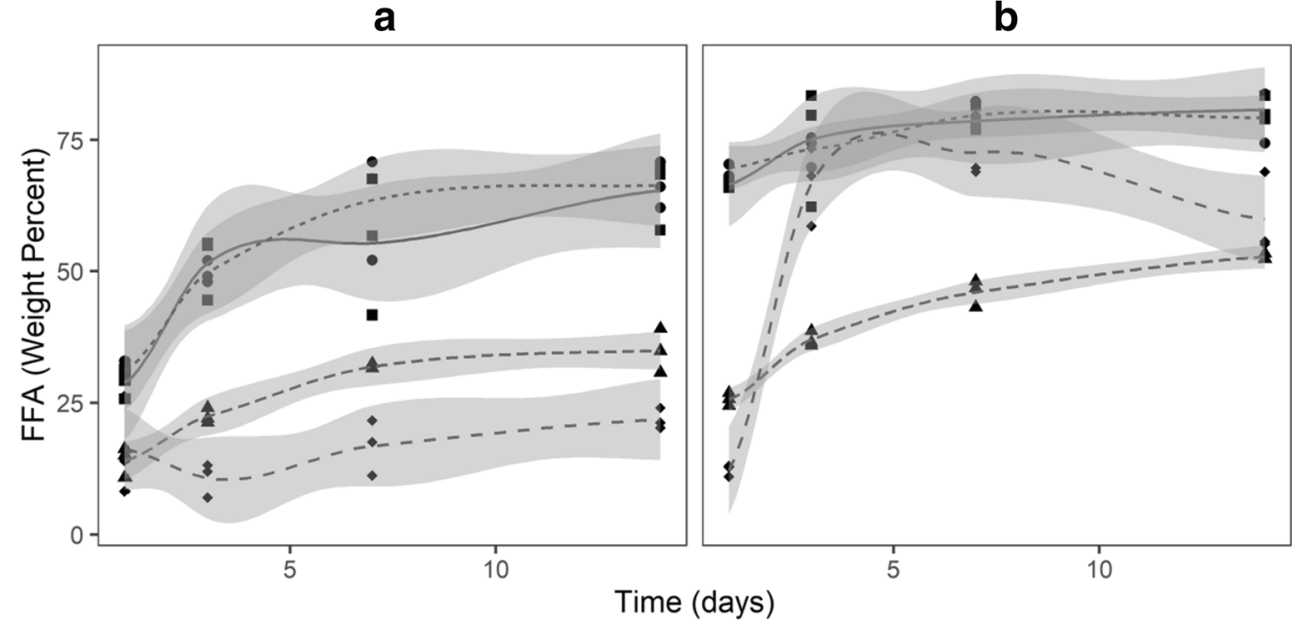

In general, the relative amount of saturated and monounsaturated fatty acids tended to increase, while the polyunsaturated fatty acids decreased in the control, benzoic acid, and formic acid samples during storage (Table 5). The changes appeared more prominent at $20{ }^{\circ} \mathrm{C}$ than at $4{ }^{\circ} \mathrm{C}$. Smaller changes were observed in the heat-treated samples compared with the other three treatments.

For the individual polyunsaturated fatty acids (PUFA), minor changes were observed for $\mathrm{C} 16: 4 \mathrm{n}-1$ (hexadecatetraenoic acid (HDTA)) and C20:5n-3 (EPA). At $4{ }^{\circ} \mathrm{C}$, the only significant decrease in HDTA during 14 days of storage occurred in formic acid samples (28-25\%). At $20{ }^{\circ} \mathrm{C}$, HDTA decreased from 32 to $29 \%, 32$ to $30 \%$, and 27 to $24 \%$ in control, benzoic acid, and formic acid samples, respectively. The relative amount of this fatty acid was stable at both temperatures in heat-treated samples. A decrease from 28 to $26 \%$ and 27 to $24 \%$ were observed for EPA in control samples at 4 and $20^{\circ} \mathrm{C}$, respectively. For the benzoic acid sample, the decrease in EPA was 28 to $26 \%$ and 28 to $27 \%$ at 4 and $20^{\circ} \mathrm{C}$, respectively. At $20{ }^{\circ} \mathrm{C}$, the relative amount of EPA in formic acid samples decreased from 32 to $30 \%$. The amount of EPA in heat-treated samples at both temperatures and formic acid samples at $4{ }^{\circ} \mathrm{C}$ remained stable during storage.

Figure 2 presents the cumulative loss of PUFA where day 1 represents $24 \mathrm{~h}$ of storage. The control and benzoic acid samples contained 80 and $81 \%$ PUFA after 1 day of storage at $4{ }^{\circ} \mathrm{C}$. The corresponding samples treated with formic acid contained $81 \%$ PUFA and the heat-treated samples contained $79 \%$ PUFA. On day 1 at $20^{\circ} \mathrm{C}$, the total amount of PUFA was $78 \%$ in the control samples, $80 \%$ in the benzoic acid and formic acid samples, and $79 \%$ in the heat-treated samples. From day 1 to day 14 of storage, the heat-treated samples were the most stable at both temperatures, with no marked decrease in total amount of PUFA. At $4{ }^{\circ} \mathrm{C}$, the benzoic acid samples lost $3.5 \%$ points of PUFA. The formic acid samples had the highest loss at $4.8 \%$ points of PUFA from day 1 to 14 of storage at $4{ }^{\circ} \mathrm{C}$. The benzoic acid samples stored at $20^{\circ} \mathrm{C}$ lost $3.0 \%$ points from day 1 to day 14 , whereas the formic acid samples and the control samples lost 5.8 and $6.6 \%$ points, respectively.

\section{Discussion}

We detected no apparent trends for the effect of pre-treatment or temperature on lipid yield. This is in accordance with previous studies on how storage affects lipid yield in microalgae biomass (Chen et al. 2012; Balduyck et al. 2016, 2017). A previous study (Ryckebosch et al. 2011) on Phaeodactylum tricornutum reported lower lipid yield in wet biomass than dried biomass after storage, which they ascribed to FFA formation during storage in wet biomass, however this was based on only one time point so no trends could be interpreted from this.

The amount of FFA increased with time in all samples with varying rate of lipolysis, and not surprisingly, the rate was generally faster at $20{ }^{\circ} \mathrm{C}$ than at $4{ }^{\circ} \mathrm{C}$. This has also been reported by Balduyck et al. (2017). They found that loss of cell wall integrity affected the lipolytic processes in the eustigmatophyte Nannochloropsis oculata and the haptophyte Tisochrysis lutea when stored at 4 and $20^{\circ} \mathrm{C}$,

Table 3 Development of lipolysis (free fatty acid (FFA) content, weight percentage) in the second storage experiment from day 0 to 14 (mean \pm standard deviation, $n=3$ ) stored at $20^{\circ} \mathrm{C}$. Control samples had no pre-treatment, other samples were heated to 70,80 , or $90{ }^{\circ} \mathrm{C}$

\begin{tabular}{lllllll}
\hline Day & 0 & 7 & & & \\
Treatment & Control & Control & $70{ }^{\circ} \mathrm{C}$ & $80{ }^{\circ} \mathrm{C}$ & $90{ }^{\circ} \mathrm{C}$ & $90{ }^{\circ} \mathrm{C}$ \\
FFA $(\%)$ & $7.2 \pm 1.2$ & $83.8 \pm 2.0$ & $68.3 \pm 9.7$ & $68.2 \pm 2.8$ & $24.6 \pm 1.6$ & $40.8 \pm 3.5$ \\
\hline
\end{tabular}


Table 4 Lipid class composition (weight percentage) from day 1 to 14 for both temperatures (mean \pm standard deviation, $n=3$ ). Control samples had no pre-treatment, $0.1 \%(\mathrm{w} / \mathrm{w})$ benzoic acid, formic acid to $\mathrm{pH} 3.0$, and heat treatment $70{ }^{\circ} \mathrm{C}$ for $30 \mathrm{~min}$. $N D$, not detected

$4{ }^{\circ} \mathrm{C} / 20{ }^{\circ} \mathrm{C}$

\begin{tabular}{llll}
\hline Day 1 & Day 3 & Day 7 & Day 14
\end{tabular}

\begin{tabular}{|c|c|c|c|c|}
\hline \multicolumn{5}{|l|}{ Triacylglycerol } \\
\hline Control & $1.9 \pm 1.7 / 4.3 \pm 1.0$ & $3.9 \pm 0.6 / 6.2 \pm 0.3$ & $2.6 \pm 0.3 / 3.5 \pm 0.6$ & $3.6 \pm 0.5 / 2.7 \pm 0.5$ \\
\hline Benzoic acid & $2.5 \pm 0.8 / 5.2 \pm 1.0$ & $3.6 \pm 0.1 / 6.4 \pm 3.0$ & $3.2 \pm 0.7 / 6.8 \pm 1.9$ & $2.9 \pm 1.0 / 3.3 \pm 0.7$ \\
\hline Formic acid & $1.9 \pm 0.3 / 1.9 \pm 0.0$ & $1.9 \pm 0.1 / 1.7 \pm 0.2$ & $1.7 \pm 0.1 / 1.8 \pm 0.1$ & $1.5 \pm 0.7 / 1.6 \pm 0.1$ \\
\hline Heat treatment & $1.7 \pm 0.3 / 2.8 \pm 0.9$ & $2.4 \pm 0.3 / 2.0 \pm 1.5$ & $1.6 \pm 0.2 / 1.9 \pm 0.6$ & $\mathrm{ND} / 3.2 \pm 1.3$ \\
\hline \multicolumn{5}{|l|}{ Diacylglycerol } \\
\hline Control & $3.2 \pm 1.3^{\mathrm{a}} / 2.2 \pm 0.4^{\mathrm{a}}$ & $3.2 \pm 1.4^{\mathrm{a}} / 5.8 \pm 2.1^{\mathrm{a}}$ & $3.3 \pm 1.1^{\mathrm{a} / 2.8} \pm 1.3^{\mathrm{a}}$ & $3.9 \pm 0.6^{\mathrm{a}} / 2.2 \pm 1.3^{\mathrm{a}}$ \\
\hline Benzoic acid & $2.7 \pm 1.6^{\mathrm{a} / 3.3 \pm 1.2^{\mathrm{ab}}}$ & $3.9 \pm 1.3^{\mathrm{a}} / 6.1 \pm 5.2^{\mathrm{a}}$ & $7.7 \pm 8.3^{\mathrm{a} / 3.2} \pm 0.7^{\mathrm{a}}$ & $3.3 \pm 1.4^{\mathrm{a}} / 2.2 \pm 1.0^{\mathrm{a}}$ \\
\hline Formic acid & $38.4 \pm 2.1^{\mathrm{b}} / 36.3 \pm 0.5^{\mathrm{C}}$ & $39.0 \pm 1.1^{\mathrm{b}} / 36.8 \pm 1.1^{\mathrm{b}}$ & $37.4 \pm 0.3^{\mathrm{b}} / 34.3 \pm 1.2^{\mathrm{b}}$ & $38.3 \pm 2.4^{\mathrm{b}} / 32.0 \pm 1.1^{* \mathrm{~b}}$ \\
\hline Heat treatment & $3.7 \pm 1.4^{\mathrm{a}} / 5.8 \pm 0.8^{\mathrm{b}}$ & $6.5 \pm 1.0^{\mathrm{a}} / 3.1 \pm 2.2^{\mathrm{a}}$ & $5.4 \pm 0.9^{\mathrm{a}} / 8.3 \pm 0.6^{\mathrm{a}}$ & $3.7 \pm 1.6^{\mathrm{a}} / 15.0 \pm 2.7^{* \mathrm{C}}$ \\
\hline \multicolumn{5}{|l|}{ Monoacylglycerol } \\
\hline Control & $5.8 \pm 0.7^{\mathrm{a}} / 6.6 \pm 0.5^{\mathrm{a}}$ & $6.4 \pm 0.1^{\mathrm{a}} / 5.0 \pm 0.6^{\mathrm{a}}$ & $8.2 \pm 0.5^{\mathrm{a}} / 4.3 \pm 0.5^{\mathrm{a}}$ & $8.9 \pm 1.2^{* \mathrm{a}} / 5.1 \pm 2.6^{\mathrm{a}}$ \\
\hline Benzoic acid & $4.9 \pm 0.1^{\mathrm{a}} / 6.8 \pm 0.3^{\mathrm{a}}$ & $6.1 \pm 0.9^{\mathrm{ab}} / 5.2 \pm 1.3^{\mathrm{a}}$ & $6.7 \pm 0.4^{\mathrm{a}} / 3.4 \pm 0.7^{\mathrm{a}}$ & $9.7 \pm 0.8^{* \mathrm{a}} / 3.9 \pm 1.6^{\mathrm{ab}}$ \\
\hline Formic acid & $1.4 \pm 0.2^{\mathrm{b}} / 1.4 \pm 0.1^{\mathrm{b}}$ & $1.4 \pm 0.0^{\mathrm{C}} / 1.6 \pm 0.2^{\mathrm{b}}$ & $1.6 \pm 0.1^{\mathrm{b}} / 1.3 \pm 1.1^{\mathrm{b}}$ & $1.7 \pm 0.1^{\mathrm{b}} / 2.0 \pm 0.1^{\mathrm{b}}$ \\
\hline Heat treatment & $4.7 \pm 1.2^{\mathrm{a}} / 4.4 \pm 0.6^{\mathrm{a}}$ & $4.2 \pm 0.8^{\mathrm{b}} / 4.2 \pm 1.3^{\mathrm{a}}$ & $4.5 \pm 0.4^{\mathrm{C}} / 4.5 \pm 0.8^{\mathrm{a}}$ & $5.6 \pm 0.1^{\mathrm{C}} / 6.4 \pm 0.2^{* \mathrm{a}}$ \\
\hline \multicolumn{5}{|l|}{ Fatty acid esters } \\
\hline Control & $3.2 \pm 1.4^{\mathrm{a}} / 3.2 \pm 0.4^{\mathrm{a}}$ & $2.9 \pm 1.3^{\mathrm{ab}} / 8.0 \pm 0.8^{*^{\mathrm{a}}}$ & $3.6 \pm 1.2^{\mathrm{a}} / 9.7 \pm 1.1^{*^{\mathrm{a}}}$ & $3.4 \pm 0.6^{\mathrm{a}} / 10.9 \pm 0.6^{*^{\mathrm{a}}}$ \\
\hline Benzoic acid & $3.2 \pm 1.3^{\mathrm{a} / 2.8} \pm 0.7^{\mathrm{ab}}$ & $3.5 \pm 0.9^{\mathrm{a}} / 5.8 \pm 0.7^{* \mathrm{~b}}$ & $2.7 \pm 0.2^{\mathrm{a}} / 8.0 \pm 0.7^{* \mathrm{a}}$ & $3.1 \pm 0.5^{\mathrm{a}} / 9.9 \pm 0.9^{* \mathrm{a}}$ \\
\hline Formic acid & $0.9 \pm 0.1^{\mathrm{b}} / 0.9 \pm 0.0^{\mathrm{b}}$ & $0.9 \pm 0.1^{\mathrm{b}} / 1.0 \pm 0.0^{\mathrm{C}}$ & $0.9 \pm 0.0^{\mathrm{b}} / 0.9 \pm 0.0^{\mathrm{b}}$ & $0.9 \pm 0.0^{\mathrm{b}} / 0.9 \pm 0.0^{\mathrm{b}}$ \\
\hline Heat treatment & $2.4 \pm 0.7^{\mathrm{ab}} / 3.4 \pm 0.3^{\mathrm{a}}$ & $3.8 \pm 0.9^{\mathrm{a}} / 3.0 \pm 1.5^{\mathrm{C}}$ & $4.3 \pm 0.5^{\mathrm{a}} / 3.5 \pm 0.9^{\mathrm{C}}$ & $3.8 \pm 0.9^{\mathrm{a}} / 5.3 \pm 0.7^{\mathrm{C}}$ \\
\hline \multicolumn{5}{|c|}{ Monogalactosyldiacylglycerol } \\
\hline Control & $28.0 \pm 7.4^{\mathrm{a}} / 2.1 \pm 0.5^{\mathrm{a}}$ & $11.5 \pm 0.3 *^{\mathrm{a}} / \mathrm{ND}^{\mathrm{a}}$ & $4.8 \pm 3.1 *^{\mathrm{a}} / \mathrm{ND}^{\mathrm{a}}$ & $3.9 \pm 1.4^{\mathrm{a}} / \mathrm{ND}^{\mathrm{a}}$ \\
\hline Benzoic acid & $31.3 \pm 4.7^{\mathrm{a}} / 2.9 \pm 1.2^{\mathrm{a}}$ & $12.8 \pm 2.7^{* a} / 0.5 \pm 0.7^{\mathrm{a}}$ & $11.0 \pm 6.6^{* \mathrm{a}} / \mathrm{ND}^{\mathrm{a}}$ & $5.1 \pm 0.5^{* a} / \mathrm{ND}^{\mathrm{a}}$ \\
\hline Formic acid & $24.9 \pm 4.8^{\mathrm{a}} / 21.7 \pm 1.0^{\mathrm{b}}$ & $21.1 \pm 1.4^{\mathrm{b}} / 9.6 \pm 0.7^{* \mathrm{~b}}$ & $12.2 \pm 1.3^{* \mathrm{a}} / 6.1 \pm 1.2^{* \mathrm{a}}$ & $10.5 \pm 1.0 * \mathrm{~b} / 3.5 \pm 0.5^{* \mathrm{a}}$ \\
\hline Heat treatment & $23.3 \pm 7.3^{\mathrm{a}} / 29.6 \pm 1.5^{\mathrm{b}}$ & $27.4 \pm 7.1^{\mathrm{b}} / 13.3 \pm 1.2^{* \mathrm{~b}}$ & $25.2 \pm 4.3^{\mathrm{b}} / 7.5 \pm 6.5^{*^{\mathrm{a}}}$ & $18.8 \pm 2.6^{\mathrm{C}} / 10.3 \pm 4.0^{* \mathrm{~b}}$ \\
\hline \multicolumn{5}{|c|}{ Digalactosyldiacylglycerol } \\
\hline Control & $1.6 \pm 1.4^{\mathrm{a}} / 0.3 \pm 0.6^{\mathrm{a}}$ & $2.4 \pm 0.6^{\mathrm{a}} / \mathrm{ND}^{\mathrm{a}}$ & $1.2 \pm 1.1^{\mathrm{a}} / \mathrm{ND}^{\mathrm{a}}$ & $0.3 \pm 0.5^{\mathrm{a}} / \mathrm{ND}^{\mathrm{a}}$ \\
\hline Benzoic acid & $2.1 \pm 0.4^{\mathrm{a}} / 1.3 \pm 0.6^{\mathrm{a}}$ & $1.8 \pm 1.7^{\mathrm{a}} / \mathrm{ND}^{\mathrm{a}}$ & $1.1 \pm 0.9^{\mathrm{a}} / \mathrm{ND}^{\mathrm{a}}$ & $0.9 \pm 0.8^{\mathrm{a}} / \mathrm{ND}^{\mathrm{a}}$ \\
\hline Formic acid & $4.4 \pm 0.8^{\mathrm{b}} / 4.5 \pm 0.1^{\mathrm{b}}$ & $4.6 \pm 0.8^{\mathrm{b}} / 5.2 \pm 0.5^{\mathrm{b}}$ & $5.9 \pm 0.6^{* \mathrm{~b}} / 4.4 \pm 0.6^{\mathrm{b}}$ & $5.2 \pm 0.2^{* \mathrm{~b}} / 2.8 \pm 0.1^{\mathrm{b}}$ \\
\hline Heat treatment & $4.4 \pm 0.4^{\mathrm{b}} / 4.1 \pm 1.5^{\mathrm{b}}$ & $3.2 \pm 0.4^{\mathrm{ab}} / 1.7 \pm 0.5^{* \mathrm{a}}$ & $4.0 \pm 0.4^{\mathrm{C}} / 0.7 \pm 0.6^{* \mathrm{a}}$ & $6.1 \pm 1.5^{* \mathrm{~b}} / \mathrm{ND}^{\mathrm{a}}$ \\
\hline \multicolumn{5}{|c|}{ Phosphatidylglycerol } \\
\hline Control & $25.2 \pm 1.1^{\mathrm{a}} / 11.6 \pm 2.2^{\mathrm{a}}$ & $20.0 \pm 1.7^{\mathrm{a}} / 1.8 \pm 1.6^{* \mathrm{a}}$ & $12.9 \pm 5.6^{* \mathrm{a}} / \mathrm{ND}^{* \mathrm{a}}$ & $9.6 \pm 1.6^{* \mathrm{a}} / \mathrm{ND}^{* \mathrm{a}}$ \\
\hline Benzoic acid & $24.6 \pm 1.5^{\mathrm{a}} / 11.1 \pm 1.4^{\mathrm{a}}$ & $16.7 \pm 3.3 * \mathrm{a} / 1.0 \pm 1.7 *^{\mathrm{a}}$ & $12.3 \pm 1.1 *^{\mathrm{a}} / \mathrm{ND}^{* \mathrm{a}}$ & $9.7 \pm 3.0^{* \mathrm{a}} / \mathrm{ND}^{* \mathrm{a}}$ \\
\hline Formic acid & $4.2 \pm 0.2^{\mathrm{b} / 3.2 \pm 0.5^{\mathrm{a}}}$ & $1.6 \pm 0.4 * \mathrm{~b} / 1.9 \pm 0.6^{\mathrm{a}}$ & $2.0 \pm 1.4 * \mathrm{~b} / 0.8 \pm 0.1 *^{\mathrm{a}}$ & $1.3 \pm 0.3 * \mathrm{k} / 0.2 \pm 0.4^{* \mathrm{a}}$ \\
\hline Heat treatment & $43.6 \pm 10.8^{\mathrm{C}} / 37.6 \pm 1.9^{\mathrm{b}}$ & $41.9 \pm 9.7^{\mathrm{C}} / 6.0 \pm 5.6^{* \mathrm{a}}$ & $38.2 \pm 1.3^{\mathrm{C}} / 1.0 \pm 1.8^{*^{\mathrm{a}}}$ & $40.1 \pm 6.1^{\mathrm{C}} / \mathrm{ND}^{* \mathrm{a}}$ \\
\hline \multicolumn{5}{|c|}{ Phosphatidylcholine } \\
\hline Control & $\mathrm{ND}^{\mathrm{a}}$ & $\mathrm{ND}^{\mathrm{a}}$ & $\mathrm{ND}^{\mathrm{a}}$ & $\mathrm{ND}^{\mathrm{a}}$ \\
\hline Benzoic acid & $\mathrm{ND}^{\mathrm{a}}$ & $\mathrm{ND}^{\mathrm{a}}$ & $\mathrm{ND}^{\mathrm{a}}$ & $\mathrm{ND}^{\mathrm{a}}$ \\
\hline Formic acid & $9.9 \pm 1.0^{\mathrm{b}} / 4.4 \pm 0.2^{\mathrm{b}}$ & $7.0 \pm 0.3^{* b} / 5.1 \pm 0.6^{b}$ & $6.3 \pm 0.3 * \mathrm{~b} / 4.5 \pm 0.1^{\mathrm{b}}$ & $5.8 \pm 0.4^{* \mathrm{~b}} / 4.2 \pm 0.3^{\mathrm{b}}$ \\
\hline Heat treatment & $\mathrm{ND}^{\mathrm{a}}$ & $\mathrm{ND}^{\mathrm{a}}$ & $\mathrm{ND}^{\mathrm{a}}$ & $\mathrm{ND}^{\mathrm{a}}$ \\
\hline
\end{tabular}

a, b, c Results in the same column and stored at the same temperature sharing superscripted letters are not significantly different $(P \geq 0.05)$

*Results significantly different from day 1 with the same pre-treatment and stored at the same temperature $(P<0.05)$

and the lipolytic processes were faster at higher temperatures. Unfortunately, the samples from day 0 in our first study were lost, but it is known that the levels of FFA in microalgae may initially be high (Artamonova et al. 2017a). However, in our 
Table 5 Fatty acid composition (weight percentage) from day 1 to 14 for both temperatures (mean \pm standard deviation, $n=3$ ). Control samples had no pre-treatment, $0.1 \%(\mathrm{w} / \mathrm{w})$ benzoic acid, formic acid to $\mathrm{pH} 3.0$, and heat treatment $70{ }^{\circ} \mathrm{C}$ for $30 \mathrm{~min}$

\begin{tabular}{|c|c|c|c|c|}
\hline & \multicolumn{4}{|l|}{$4^{\circ} \mathrm{C} / 20^{\circ} \mathrm{C}$} \\
\hline & Day 1 & Day 3 & Day 7 & Day 14 \\
\hline \multicolumn{5}{|l|}{ C14:0 } \\
\hline Control & $3.9 \pm 0.1^{\mathrm{a}} / 5.7 \pm 0.0^{\mathrm{a}}$ & $4.4 \pm 0.4^{\mathrm{a}} / 5.6 \pm 0.2^{\mathrm{a}}$ & $5.2 \pm 0.4^{\mathrm{a}} / 6.8 \pm 1.5^{\mathrm{a}}$ & $5.9 \pm 0.8^{\mathrm{a} / 7.4 \pm 1.6^{\mathrm{a}}}$ \\
\hline Benzoic acid & $4.4 \pm 0.2^{\mathrm{a}} / 5.1 \pm 0.1^{\mathrm{b}}$ & $4.6 \pm 0.1^{\mathrm{a}} / 5.5 \pm 0.2^{\mathrm{a}}$ & $4.7 \pm 0.2^{\mathrm{a}} / 5.6 \pm 0.1^{\mathrm{ab}}$ & $5.4 \pm 0.0 * \mathrm{a} / 6.2 \pm 0.3 * \mathrm{ab}$ \\
\hline Formic acid & $4.0 \pm 0.1^{\mathrm{a}} / 4.2 \pm 0.1^{\mathrm{c}}$ & $4.2 \pm 0.2^{\mathrm{a}} / 4.7 \pm 0.3^{\mathrm{b}}$ & $4.5 \pm 0.2 * \mathrm{a} / 4.8 \pm 0.2 * \mathrm{~b}$ & $4.5 \pm 0.1 * \mathrm{a} / 5.3 \pm 0.1^{* \mathrm{bc}}$ \\
\hline Heat treatment & $5.8 \pm 0.4^{\mathrm{b}} / 5.6 \pm 0.1^{\mathrm{D}}$ & $5.5 \pm 0.4^{\mathrm{b}} / 4.7 \pm 0.3^{* \mathrm{~b}}$ & $5.6 \pm 0.1^{\mathrm{a}} / 4.5 \pm 0.1^{\mathrm{b}}$ & $5.5 \pm 0.1^{\mathrm{a} / 4.2} \pm 0.2^{* \mathrm{c}}$ \\
\hline \multicolumn{5}{|l|}{ C16:0 } \\
\hline Control & $4.2 \pm 0.0^{\mathrm{a}} / 4.3 \pm 0.1^{\mathrm{a}}$ & $4.1 \pm 0.2^{\mathrm{a}} / 4.3 \pm 0.0^{\mathrm{a}}$ & $4.3 \pm 0.3^{\mathrm{a}} / 5.5 \pm 0.9^{\mathrm{a}}$ & $5.0 \pm 0.7^{\mathrm{ab} / 5.9} \pm 1.2^{* \mathrm{a}}$ \\
\hline Benzoic acid & $4.0 \pm 0.2^{\mathrm{ab}} / 3.8 \pm 0.1^{\mathrm{b}}$ & $4.3 \pm 0.2^{\mathrm{a}} / 4.1 \pm 0.2^{\mathrm{a}}$ & $4.3 \pm 0.3^{\mathrm{a}} / 4.4 \pm 0.4^{* \mathrm{~b}}$ & $4.7 \pm 0.1 * \mathrm{ab} / 4.5 \pm 0.1 *^{\mathrm{b}}$ \\
\hline Formic acid & $4.0 \pm 0.1^{\mathrm{ab}} / 4.3 \pm 0.1^{\mathrm{a}}$ & $4.3 \pm 0.2^{\mathrm{a}} / 5.4 \pm 0.4^{* \mathrm{~b}}$ & $4.9 \pm 0.1 *^{\mathrm{a}} / 5.8 \pm 0.1 *^{\mathrm{a}}$ & $5.4 \pm 0.1 * \mathrm{a} / 6.2 \pm 0.0 *^{\mathrm{a}}$ \\
\hline Heat treatment & $3.8 \pm 0.1^{\mathrm{b}} / 4.1 \pm 0.0^{\mathrm{a}}$ & $4.1 \pm 0.2^{\mathrm{a}} / 4.0 \pm 0.2^{\mathrm{a}}$ & $4.1 \pm 0.1^{\mathrm{a}} / 4.3 \pm 0.1^{\mathrm{b}}$ & $4.1 \pm 0.1^{\mathrm{b}} / 4.5 \pm 0.0^{* \mathrm{~b}}$ \\
\hline \multicolumn{5}{|l|}{ C18:0 } \\
\hline Control & $1.3 \pm 0.0^{\mathrm{a}} / 1.2 \pm 0.0^{\mathrm{a}}$ & $1.2 \pm 0.1^{\mathrm{a} / 1.1 \pm 0.0^{\mathrm{ab}}}$ & $1.2 \pm 0.1^{\mathrm{a}} / 1.4 \pm 0.2^{\mathrm{a}}$ & $1.4 \pm 0.3^{\mathrm{a}} / 1.4 \pm 0.3^{\mathrm{a}}$ \\
\hline Benzoic acid & $1.1 \pm 0.2^{\mathrm{b}} / 0.9 \pm 0.1^{\mathrm{b}}$ & $1.3 \pm 0.2^{\mathrm{a}} / 0.9 \pm 0.1^{\mathrm{a}}$ & $1.3 \pm 0.2^{\mathrm{a}} / 1.1 \pm 0.1^{\mathrm{b}}$ & $1.2 \pm 0.0^{\mathrm{a}} / 1.0 \pm 0.1^{\mathrm{b}}$ \\
\hline Formic acid & $1.3 \pm 0.1^{\mathrm{a}} / 1.3 \pm 0.0^{\mathrm{a}}$ & $1.5 \pm 0.1 * \mathrm{a} / 1.3 \pm 0.1^{\mathrm{b}}$ & $1.4 \pm 0.0^{\mathrm{a}} / 1.2 \pm 0.1^{\mathrm{ab}}$ & $1.4 \pm 0.1^{\mathrm{a}} / 1.2 \pm 0.0^{\mathrm{ab}}$ \\
\hline Heat treatment & $1.0 \pm 0.1^{\mathrm{b}} / 1.2 \pm 0.0^{\mathrm{a}}$ & $1.2 \pm 0.2^{\mathrm{a}} / 1.1 \pm 0.2^{\mathrm{ab}}$ & $1.2 \pm 0.1^{\mathrm{a}} / 1.1 \pm 0.1^{\mathrm{ab}}$ & $1.2 \pm 0.0^{\mathrm{a}} / 1.2 \pm 0.0^{\mathrm{ab}}$ \\
\hline \multicolumn{5}{|l|}{ C16:1n-7 } \\
\hline Control & $10.1 \pm 0.0^{\mathrm{a}} / 10.8 \pm 0.2^{\mathrm{a}}$ & $10.2 \pm 0.0^{\mathrm{a}} / 11.1 \pm 0.1^{\mathrm{a}}$ & $11.0 \pm 0.0^{\mathrm{ab}} / 11.9 \pm 0.8^{\mathrm{a}}$ & $11.3 \pm 0.3^{\mathrm{a}} / 13.5 \pm 2.2^{*^{\mathrm{a}}}$ \\
\hline Benzoic acid & $10.1 \pm 0.1^{\mathrm{a}} / 10.4 \pm 0.0^{\mathrm{b}}$ & $10.3 \pm 0.0^{\mathrm{a}} / 10.9 \pm 0.1^{\mathrm{a}}$ & $10.6 \pm 0.2^{\mathrm{a}} / 11.1 \pm 0.3^{\mathrm{ab}}$ & $11.7 \pm 0.1^{* a} / 11.6 \pm 0.7^{* a b}$ \\
\hline Formic acid & $9.7 \pm 0.3^{\mathrm{b}} / 10.7 \pm 0.1^{\mathrm{ab}}$ & $10.5 \pm 0.3^{* a} / 12.3 \pm 0.6^{* b}$ & $11.7 \pm 0.3 * \mathrm{~b} / 12.7 \pm 0.2 * \mathrm{c}$ & $12.4 \pm 0.1 * \mathrm{a} / 13.5 \pm 0.1 *^{\mathrm{a}}$ \\
\hline Heat treatment & $10.5 \pm 0.1^{\mathrm{c}} / 10.5 \pm 0.0^{\mathrm{ab}}$ & $10.5 \pm 0.1^{\mathrm{a}} / 10.6 \pm 0.2^{\mathrm{a}}$ & $10.5 \pm 0.1^{\mathrm{a}} / 11.0 \pm 0.1^{\mathrm{b}}$ & $10.5 \pm 0.0^{\mathrm{a}} / 11.2 \pm 0.2^{* \mathrm{~b}}$ \\
\hline \multicolumn{5}{|l|}{ C16:2n-4 } \\
\hline Control & $2.4 \pm 0.0^{\mathrm{a}} / 2.5 \pm 0.1^{\mathrm{a}}$ & $2.5 \pm 0.0^{\mathrm{a}} / 2.5 \pm 0.0^{\mathrm{a}}$ & $2.5 \pm 0.0^{\mathrm{a}} / 2.4 \pm 0.1^{\mathrm{a}}$ & $2.6 \pm 0.0^{\mathrm{a}} / 2.5 \pm 0.1^{\mathrm{a}}$ \\
\hline Benzoic acid & $2.4 \pm 0.0^{\mathrm{a}} / 2.4 \pm 0.0^{\mathrm{a}}$ & $2.5 \pm 0.0^{\mathrm{a}} / 2.4 \pm 0.0^{\mathrm{a}}$ & $2.5 \pm 0.0^{\mathrm{a}} / 2.4 \pm 0.0^{\mathrm{a}}$ & $2.6 \pm 0.0^{* \mathrm{a}} / 2.5 \pm 0.1 *^{\mathrm{ab}}$ \\
\hline Formic acid & $5.3 \pm 0.1^{\mathrm{b} / 5.2 \pm 0.1^{\mathrm{b}}}$ & $5.2 \pm 0.1^{\mathrm{b}} / 5.0 \pm 0.1^{\mathrm{b}}$ & $5.1 \pm 0.1 * \mathrm{~b} / 4.8 \pm 0.1 * \mathrm{~b}$ & $4.9 \pm 0.0^{* \mathrm{~b}} / 4.9 \pm 0.0^{* \mathrm{c}}$ \\
\hline Heat treatment & $2.5 \pm 0.0^{\mathrm{a}} / 2.4 \pm 0.0^{\mathrm{a}}$ & $2.4 \pm 0.0^{\mathrm{a}} / 2.4 \pm 0.0^{\mathrm{a}}$ & $2.5 \pm 0.0^{\mathrm{a}} / 2.5 \pm 0.0^{\mathrm{a}}$ & $2.5 \pm 0.0^{\mathrm{c}} / 2.4 \pm 0.0^{\mathrm{b}}$ \\
\hline \multicolumn{5}{|l|}{ C16:3n-4 } \\
\hline Control & $4.8 \pm 0.1^{\mathrm{ab}} / 4.7 \pm 0.1^{\mathrm{a}}$ & $4.8 \pm 0.0^{\mathrm{a}} / 4.6 \pm 0.0^{\mathrm{a}}$ & $4.8 \pm 0.0^{\mathrm{a}} / 4.5 \pm 0.1^{\mathrm{a}}$ & $4.8 \pm 0.0^{\mathrm{a}} / 4.4 \pm 0.2^{* \mathrm{a}}$ \\
\hline Benzoic acid & $4.9 \pm 0.0^{\mathrm{a}} / 4.6 \pm 0.0^{\mathrm{a}}$ & $4.8 \pm 0.0^{\mathrm{a}} / 4.5 \pm 0.0^{* \mathrm{a}}$ & $4.7 \pm 0.0 * \mathrm{a} / 4.4 \pm 0.1 *^{* \mathrm{a}}$ & $4.8 \pm 0.1^{\mathrm{a}} / 4.5 \pm 0.0^{* \mathrm{a}}$ \\
\hline Formic acid & $9.4 \pm 0.1^{\mathrm{c} / 9.0} \pm 0.0^{\mathrm{b}}$ & $9.1 \pm 0.1 * \mathrm{~b} / 8.5 \pm 0.1 * \mathrm{~b}$ & $8.7 \pm 0.0^{* \mathrm{~b}} / 8.2 \pm 0.0^{* \mathrm{~b}}$ & $8.3 \pm 0.0^{* \mathrm{~b}} / 8.0 \pm 0.0^{* \mathrm{~b}}$ \\
\hline Heat treatment & $4.7 \pm 0.1^{\mathrm{b}} / 4.6 \pm 0.0^{\mathrm{c}}$ & $4.6 \pm 0.0^{\mathrm{c}} / 4.7 \pm 0.0^{\mathrm{c}}$ & $4.6 \pm 0.0^{\mathrm{c}} / 4.7 \pm 0.0^{\mathrm{c}}$ & $4.6 \pm 0.0^{\mathrm{a}} / 4.7 \pm 0.0^{\mathrm{c}}$ \\
\hline \multicolumn{5}{|l|}{ C16:4n-1 } \\
\hline Control & 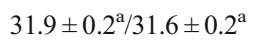 & $32.2 \pm 0.1^{\mathrm{a} / 31.1} \pm 0.1^{\mathrm{a}}$ & $31.5 \pm 0.2^{\mathrm{a}} / 29.5 \pm 1.1^{\mathrm{a}}$ & $31.0 \pm 0.8^{\mathrm{a}} / 28.9 \pm 2.1^{*^{\mathrm{a}}}$ \\
\hline Benzoic acid & $32.6 \pm 0.1^{\mathrm{b}} / 31.5 \pm 0.1^{\mathrm{a}}$ & $32.1 \pm 0.4^{\mathrm{a}} / 30.9 \pm 0.0^{\mathrm{a}}$ & $31.7 \pm 0.3 * \mathrm{a} / 29.9 \pm 0.9 *^{\mathrm{a}}$ & $31.4 \pm 0.4^{* a} / 30.2 \pm 0.1 *^{\mathrm{ab}}$ \\
\hline Formic acid & $28.0 \pm 0.1^{\mathrm{c}} / 26.7 \pm 0.1^{\mathrm{b}}$ & $26.9 \pm 0.1 * \mathrm{~b} / 25.0 \pm 0.2{ }^{* \mathrm{~b}}$ & $25.6 \pm 0.0^{* \mathrm{~b}} / 24.2 \pm 0.1 * \mathrm{~b}$ & $24.6 \pm 0.1^{* \mathrm{~b}} / 23.5 \pm 0.1^{* \mathrm{c}}$ \\
\hline Heat treatment & $31.8 \pm 0.6^{\mathrm{a} / 31.5} \pm 0.2^{\mathrm{a}}$ & $31.5 \pm 0.1^{\mathrm{c} / 31.7} \pm 0.3^{\mathrm{c}}$ & $31.5 \pm 0.0^{\mathrm{a}} / 31.4 \pm 0.1^{\mathrm{c}}$ & $31.4 \pm 0.1^{\mathrm{a}} / 31.5 \pm 0.2^{\mathrm{b}}$ \\
\hline \multicolumn{5}{|l|}{ C18:4n-3 } \\
\hline Control & $10.0 \pm 0.0^{\mathrm{a}} / 9.9 \pm 0.1^{\mathrm{a}}$ & $9.8 \pm 0.0^{\mathrm{ab}} / 9.3 \pm 0.1^{\mathrm{a}}$ & $9.7 \pm 0.1^{\mathrm{a}} / 9.0 \pm 0.5^{\mathrm{a}}$ & $9.5 \pm 0.3^{\mathrm{a}} / 9.0 \pm 0.5^{*^{\mathrm{a}}}$ \\
\hline Benzoic acid & $9.9 \pm 0.0^{\mathrm{b}} / 10.1 \pm 0.0^{\mathrm{b}}$ & $9.7 \pm 0.1^{\mathrm{a}} / 9.9 \pm 0.1^{\mathrm{b}}$ & $9.8 \pm 0.0^{\mathrm{a}} / 9.8 \pm 0.4^{\mathrm{b}}$ & $9.6 \pm 0.1^{\mathrm{ab}} / 10.0 \pm 0.1^{\mathrm{b}}$ \\
\hline Formic acid & $3.7 \pm 0.0^{\mathrm{c}} / 3.5 \pm 0.0^{\mathrm{c}}$ & $3.5 \pm 0.1^{\mathrm{c}} / 3.6 \pm 0.1^{\mathrm{c}}$ & $3.6 \pm 0.0^{\mathrm{b}} / 3.7 \pm 0.0^{* \mathrm{c}}$ & $3.7 \pm 0.1^{\mathrm{c}} / 3.8 \pm 0.0^{* \mathrm{c}}$ \\
\hline Heat treatment & $10.1 \pm 0.1^{\mathrm{a}} / 10.0 \pm 0.0^{\mathrm{b}}$ & $10.1 \pm 0.0^{\mathrm{b}} / 9.9 \pm 0.2^{\mathrm{b}}$ & $10.0 \pm 0.0^{\mathrm{a}} / 9.6 \pm 0.0^{\mathrm{b}}$ & $10.1 \pm 0.0^{\mathrm{b}} / 9.3 \pm 0.1^{* \mathrm{a}}$ \\
\hline \multicolumn{5}{|l|}{$C 20 \cdot 5 n-3$} \\
\hline Control & $28.3 \pm 0.1^{\mathrm{a}} / 26.6 \pm 0.4^{\mathrm{ab}}$ & $27.8 \pm 0.1^{\mathrm{a}} / 27.5 \pm 0.2^{\mathrm{a}}$ & $26.9 \pm 0.4^{\mathrm{a}} / 25.8 \pm 1.2^{\mathrm{a}}$ & $25.8 \pm 1.1^{* \mathrm{a}} / 24.2 \pm 2.1^{* \mathrm{a}}$ \\
\hline Benzoic acid & $27.8 \pm 0.1^{\mathrm{ab}} / 28.0 \pm 0.1^{\mathrm{a}}$ & $27.5 \pm 0.1^{\mathrm{a}} / 27.7 \pm 0.2^{\mathrm{a}}$ & $27.6 \pm 0.2^{\mathrm{a}} / 27.7 \pm 0.1^{\mathrm{ab}}$ & $25.9 \pm 0.2^{* a} / 26.7 \pm 0.7 * a b$ \\
\hline Formic acid & $31.5 \pm 0.4^{\mathrm{c}} / 32.3 \pm 0.4^{\mathrm{c}}$ & $31.7 \pm 0.8^{\mathrm{b}} / 31.3 \pm 1.2^{\mathrm{b}}$ & $31.6 \pm 0.5^{\mathrm{b}} / 31.2 \pm 0.4^{\mathrm{c}}$ & $31.7 \pm 0.1^{\mathrm{b}} / 30.0 \pm 0.2^{* \mathrm{c}}$ \\
\hline Heat treatment & $27.1 \pm 0.4^{\mathrm{b}} / 27.1 \pm 0.1^{\mathrm{b}}$ & $27.2 \pm 0.2^{\mathrm{a}} / 27.9 \pm 0.2^{*^{\mathrm{a}}}$ & $27.1 \pm 0.1^{\mathrm{a}} / 27.9 \pm 0.1^{\mathrm{b}}$ & $27.3 \pm 0.1^{\mathrm{a}} / 27.9 \pm 0.3^{* \mathrm{bc}}$ \\
\hline \multicolumn{5}{|l|}{ C22:6n-3 } \\
\hline Control & $2.9 \pm 0.1^{\mathrm{ab}} / 2.7 \pm 0.2^{\mathrm{a}}$ & $2.9 \pm 0.0^{\mathrm{a}} / 3.0 \pm 0.0^{\mathrm{a}}$ & $2.8 \pm 0.1^{\mathrm{a} / 3.1} \pm 0.2^{\mathrm{a}}$ & $2.8 \pm 0.1^{* \mathrm{ab}} / 2.8 \pm 0.3^{\mathrm{a}}$ \\
\hline Benzoic acid & $2.9 \pm 0.1^{\mathrm{ab}} / 3.0 \pm 0.0^{\mathrm{a}}$ & $2.9 \pm 0.0^{\mathrm{a}} / 2.9 \pm 0.0^{\mathrm{a}}$ & $2.8 \pm 0.0^{\mathrm{a}} / 3.0 \pm 0.1^{\mathrm{a}}$ & $2.6 \pm 0.0^{* \mathrm{a}} / 2.9 \pm 0.1^{\mathrm{a}}$ \\
\hline Formic acid & $3.2 \pm 0.2^{\mathrm{a}} / 2.9 \pm 0.1^{\mathrm{a}}$ & $2.9 \pm 0.1 * \mathrm{a} / 2.9 \pm 0.2^{\mathrm{a}}$ & $2.9 \pm 0.0 * \mathrm{a} / 3.4 \pm 0.0 * \mathrm{~b}$ & $3.1 \pm 0.1^{\mathrm{b}} / 3.6 \pm 0.0^{* \mathrm{~b}}$ \\
\hline Heat treatment & $2.6 \pm 0.4^{\mathrm{b}} / 2.8 \pm 0.0^{\mathrm{a}}$ & $2.8 \pm 0.0^{\mathrm{a}} / 3.0 \pm 0.1^{\mathrm{a}}$ & $2.8 \pm 0.0^{\mathrm{a}} / 3.0 \pm 0.0^{\mathrm{a}}$ & $2.8 \pm 0.0^{\mathrm{ab}} / 3.0 \pm 0.0^{\mathrm{a}}$ \\
\hline
\end{tabular}

a, b, c Results in the same column and stored at the same temperature sharing superscripted letters are not significantly different $(P \geq 0.05)$

*Results significantly different from day 1 with the same pre-treatment and stored at the same temperature $(P<0.05)$

follow-up study of temperature treatment, the initial FFA content was 7\%. One reason for high initial levels of FFA may be that the centrifugation process during harvesting damages the cells initiating enzymatic hydrolysis.
The rapid formation of FFA in diatoms has been attributed to grazer defense mechanisms, where the fatty acids are released from the glycerol backbones via hydrolytic enzymes to produce oxylipins downstream (d'Ippolito et al. 2004; 
Fig. 2 Polyunsaturated fatty acids (PUFA, weight percentage) from day 1 to 14 for each treatment $(\mathrm{n}=3)$ at $4(\mathrm{~A})$ and $20^{\circ} \mathrm{C}(\mathrm{B})$. Benzoic acid $(0.1 \%(\mathrm{w} / \mathrm{w})$, square), control (no pre-treatment, circle), formic acid ( $\mathrm{pH} 3.0$, triangle), and heat treatment $\left(70{ }^{\circ} \mathrm{C}\right.$ for $30 \mathrm{~min}$, diamond)

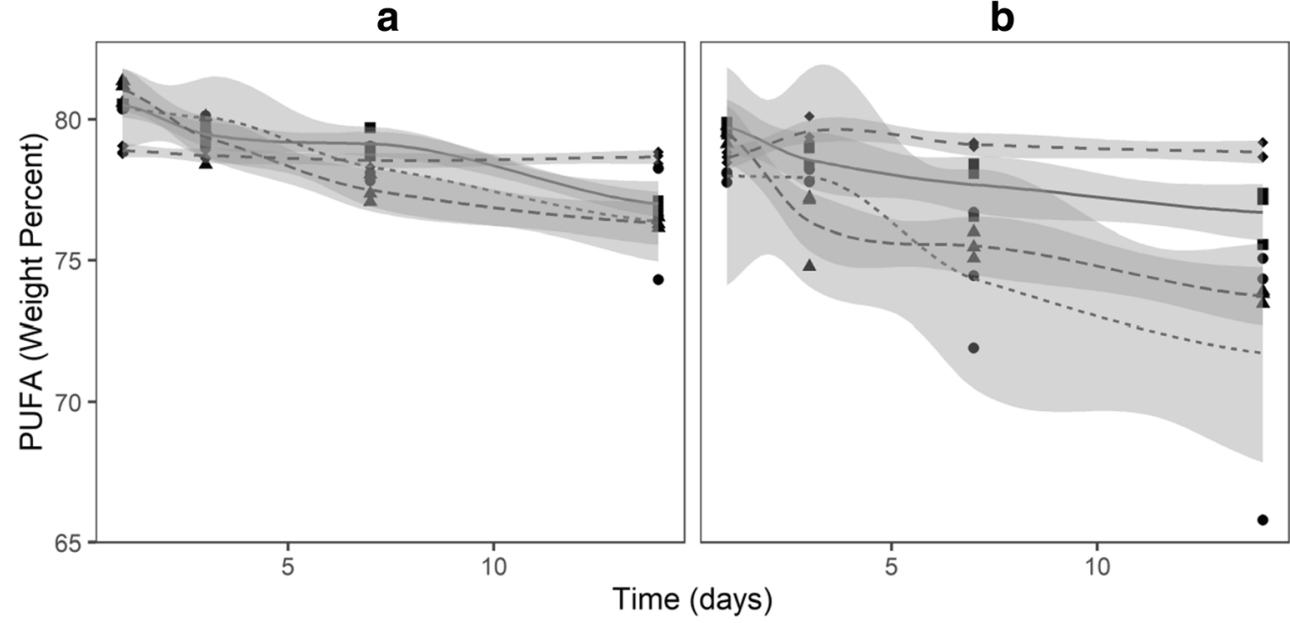

Wichard et al. 2007; Gerecht et al. 2011). The inhibiting effect of heat treatment on formation of FFA has previously been reported in other diatoms such as Pseudo-nitzschia pungens and Pseudo-nitzschia multiseries (Budge and Parrish 1999) and Skeletonema costatum (Berge et al. 1995). In both these studies, boiling water was poured over the biomass pellets to inactivate the lipolytic enzymes. In a recent study, Balduyck et al. (2019) found a heat treatment of $80{ }^{\circ} \mathrm{C}$ for $8 \mathrm{~min}$ in a water bath sufficient to inhibit the lipolytic reactions in T. lutea for 7 days of storage at $4{ }^{\circ} \mathrm{C}$, whereas $65{ }^{\circ} \mathrm{C}$ was not enough. In formic acid samples, the formation of FFA was also slowed down and this indicates that a $\mathrm{pH}$ of 3.0 is enough to substantially inhibit the lipolytic enzymes. In hazelnut, lipase activity was inhibited at a $\mathrm{pH}$ of 3.5 (Seyhan et al. 2002), which is in accordance with our findings. In contrast, a pH of 4.0 was not enough to inhibit lipolytic reactions in T. lutea (Balduyck et al. 2016). It would clearly be of interest to study the combined use of heat treatment and lowering of $\mathrm{pH}$ on the formation of FFA in microalgae biomass.

d'Ippolito et al. (2004) found glycolipids to be the main sources for oxylipin production in S. costatum, whereas phospholipids played only a minor role. In this study, we found a large decrease in PG for most samples during storage, indicating lipolytic degradation of this class even though it may not be strictly involved in oxylipin formation. Another explanation may be that there is a difference in the oxylipin pathway in P. glacialis compared with $S$. costatum. The susceptibility of polar lipid classes to lipolysis during storage of microalgae biomass has also been reported for other species as well (Berge et al. 1995; Balduyck et al. 2016).

The samples used in formic acid treatment were harvested at a different time than the other samples, which probably explains the differences in initial lipid class composition. It is known that the lipid class composition of diatoms is affected by the culture age when harvesting microalgae from a continuous cultivation (Alonso et al. 2000).
Based on the formation of FFA, heating to $70{ }^{\circ} \mathrm{C}$ was apparently not enough to inactivate the lipolytic enzymes completely, but at a storage temperature of $4{ }^{\circ} \mathrm{C}$, the activity of these enzymes appeared to be very low. For lipolysis to be slowed down at a $20^{\circ} \mathrm{C}$ storage temperature, the samples had to be heated to $90{ }^{\circ} \mathrm{C}$ before storage, heating the samples to $80^{\circ} \mathrm{C}$ was not enough. Some exogenous enzymes of microbial origin may have contributed to the formation of FFA during prolonged storage, in particular at $20^{\circ} \mathrm{C}$ and neutral $\mathrm{pH}$. It has previously been investigated whether the lipolysis in microalgae was caused by endogenous enzymes or by exogenous microbial lipases. Some have concluded that the origin was endogenous (Balduyck et al. 2016) whereas others have found indications of bacterial activity (Budge and Parrish 1999). The level of benzoic acid in our samples was based on the amount usually added to foodstuff to inhibit microbial growth and did not affect the $\mathrm{pH}$ of the samples. This was important to separate whether the effect from benzoic acid and formic acid was mainly a $\mathrm{pH}$ effect or an antimicrobial effect. Our results indicate an effect of $\mathrm{pH}$ rather than an antimicrobial effect.

Lipases from psychrophilic organisms are commonly inactivated at lower heating temperatures, however such enzymes have been reported to have high resistance to irreversible heat inactivation (Owusu et al. 1992; Makhzoum et al. 1993). Additionally, psychrophilic enzymes have a lower optimum temperature, usually around $20^{\circ} \mathrm{C}$, than enzymes from mesophilic organisms (Feller and Gerday 2003). The heat treatment applied in this study may have left some active lipases, therefore to avoid lipolysis during storage, it may be essential to apply lower storage temperatures. Storage of mesophilic microalgae has been studied much more extensively than psychrophilic microalgae, and these have reported lower development of free fatty acids (Balduyck et al. 2016, 2019). The much higher formation of free fatty acids in this study may be explained by the low optimum temperatures of enzymes in psychrophilic organisms compared with 
mesophilic organisms during storage of biomass at refrigeration or room temperature.

The omega- 3 content of diatoms stored at refrigerator temperatures has previously been found to decrease rapidly (Welladsen et al. 2014), but a heat treatment appears to make the omega-3 content more stable during storage of microalgae (Budge and Parrish 1999; Balduyck et al. 2019) which is similar to our results for the diatom $P$. glacialis.

The loss of PUFA may stem from endogenous enzyme activities, as production of oxylipins via lipoxygenase requires PUFA of a certain kind (Fontana et al. 2007). The other explanation for the loss of PUFA may be autoxidation, to which these fatty acids are very susceptible. Budge and Parrish (1999) found that heat treatment inhibited PUFA degradation. They speculated that the heat treatment might have inhibited some mechanism of PUFA degradation either by less PUFA available as FFA, which could be more exposed to autoxidation or lipoxygenase, or that the heat treatment inactivated the lipoxygenase enzymes. Previous studies have established that PUFA as FFA are more prone to autoxidation (Miyashita and Takagi 1986). However, the FFA content of the formic acid and heat-treated samples in our study was similar, yet the decrease of PUFA content was larger in the formic acid samples at $20^{\circ} \mathrm{C}$. It could well be that both formic acid and heat treatment are able to inhibit the enzymatic oxidation, and that the loss of PUFA in the formic acid samples is caused by the low $\mathrm{pH}$. It has previously been proposed that low $\mathrm{pH}$ accelerates autoxidation of fish oil-enriched mayonnaise (Jacobsen et al. 2001) and in fish silage stabilized with formic acid (Ozyurt et al. 2018). However, commonly used methods for evaluating oxidation parameters are usually titrative (peroxide value) or spectrophotometric (peroxide value, anisidine value, conjugated dienes, and thiobarbituric acid reactive substances). The amount of pigments in microalgae biomass may interfere with the readouts from these methods (Safafar et al. 2017) and oxidation parameters were therefore not analyzed in this study.

\section{Conclusions}

Lipids were best preserved in heat-treated biomass stored at $4{ }^{\circ} \mathrm{C}$, with regards to both the development of free fatty acids and reduction in PUFA level. Mainly, polar lipids were hydrolyzed to free fatty acids. Formic acid as pre-treatment reduced the amount of lipolysis during storage but was not able to inhibit PUFA deterioration to the same extent as heat treatment. Benzoic acid and control samples showed similar trends for lipid deterioration during storage and displayed high lipolytic activity. The effect of heat treatment on both lipid class and fatty acid composition, and the lack of effect from benzoic acid treatment, indicate that the degradation of lipids stems from endogenous enzymes of $P$. glacialis rather than exogenous enzymes from other microorganisms. The rate of lipid deterioration in this psychrophilic diatom was highest at $20{ }^{\circ} \mathrm{C}$, so refrigeration seems prudent for storage over several days.

Acknowledgments Open Access funding provided by UiT The Arctic University of Norway. The authors wish to thank Linn Jakobsen Kristiansen, Therese Smelror Løkken, and Gunilla Eriksen for their help with algae cultivation and harvesting.

Authors' contributions Conception: Lars Dalheim and Jon Brage Svenning

Data collection: Lars Dalheim and Jon Brage Svenning

Data analysis and interpretation: Lars Dalheim and Jon Brage Svenning

Drafting of the article: Lars Dalheim, Ragnar Ludvig Olsen, and Jon Brage Svenning

Critical revision of the article: Ragnar Ludvig Olsen, Terje Vasskog, and Hans Christian Eilertsen

Final approval of the version to be published: Lars Dalheim, Jon Brage Svenning, Ragnar Ludvig Olsen, Terje Vasskog, and Hans Christian Eilertsen

Funding This project is funded by Troms County Regional Funds no. TFK2017-066, UiT The Arctic University of Norway, and Finnfjord AS.

Data availability Data for this experiment are available from the Open Science Framework (OSF (https://osf.io/6nu9t/?view_only= a6a240b97c3c4d518a2e2222de901772)) under the name "Stability of lipids during wet storage of the marine diatom Porosira glacialis under semi-preserved conditions at 4 and $20^{\circ} \mathrm{C}$."

\section{Compliance with ethical standards}

Conflict of interest The authors declare that they have no conflict of interest.

Code availability The $\mathrm{R}$ script for this experiment is available from the Open Science Framework (OSF (https://osf.io/6nu9t/?view only= a6a240b97c3c4d518a2e2222de901772)) under the name "Stability of lipids during wet storage of the marine diatom Porosira glacialis under semi-preserved conditions at 4 and $20^{\circ} \mathrm{C}$ ".

Open Access This article is licensed under a Creative Commons Attribution 4.0 International License, which permits use, sharing, adaptation, distribution and reproduction in any medium or format, as long as you give appropriate credit to the original author(s) and the source, provide a link to the Creative Commons licence, and indicate if changes were made. The images or other third party material in this article are included in the article's Creative Commons licence, unless indicated otherwise in a credit line to the material. If material is not included in the article's Creative Commons licence and your intended use is not permitted by statutory regulation or exceeds the permitted use, you will need to obtain permission directly from the copyright holder. To view a copy of this licence, visit http://creativecommons.org/licenses/by/4.0/.

\section{References}

Abreu S, Solgadi A, Chaminade P (2017) Optimization of normal phase chromatographic conditions for lipid analysis and comparison of associated detection techniques. J Chromatogr A 1514:54-71 
Alonso DL, Belarbi EH, Fernandez-Sevilla JM, Rodriguez-Ruiz J, Grima EM (2000) Acyl lipid composition variation related to culture age and nitrogen concentration in continuous culture of the microalga Phaeodactylum tricornutum. Phytochemistry 54:461-471

Artamonova EY, Svenning JB, Vasskog T, Hansen E, Eilertsen HC (2017a) Analysis of phospholipids and neutral lipids in three common northern cold water diatoms: Coscinodiscus concinnus, Porosira glacialis, and Chaetoceros socialis, by ultra-high performance liquid chromatography-mass spectrometry. J Appl Phycol 29:1241-1249

Artamonova EY, Vasskog T, Eilertsen HC (2017b) Lipid content and fatty acid composition of Porosira glacialis and Attheya longicornis in response to carbon dioxide $\left(\mathrm{CO}_{2}\right)$ aeration. PLoS One 12:9

Balduyck L, Bijttebier S, Bruneel C, Jacobs G, Voorspoels S, Van Durme J, Muylaert K, Foubert I (2016) Lipolysis in T-Isochrysis lutea during wet storage at different temperatures. Algal Res 18:281-287

Balduyck L, Dejonghe C, Goos P, Jooken E, Muylaert K, Foubert I (2019) Inhibition of lipolytic reactions during wet storage of TIsochrysis lutea biomass by heat treatment. Algal Res 38:10

Balduyck L, Stock T, Bijttebier S, Bruneel C, Jacobs G, Voorspoels S, Muylaert K, Foubert I (2017) Integrity of the microalgal cell plays a major role in the lipolytic stability during wet storage. Algal Res 25: 516-524

Barkia I, Saari N, Manning SR (2019) Microalgae for high-value products towards human health and nutrition. Mar Drugs 17:29

Berge JP, Gouygou JP, Dubacq JP, Durand P (1995) Reassessment of lipid-composition of the diatom, Skeletonema costatum. Phytochemistry 39:1017-1021

Botte P, d'Ippolito G, Gallo C, Sardo A, Fontana A (2018) Combined exploitation of $\mathrm{CO}_{2}$ and nutrient replenishment for increasing biomass and lipid productivity of the marine diatoms Thalassiosira weissflogii and Cyclotella cryptica. J Appl Phycol 30:243-251

Budge SM, Parrish CC (1999) Lipid class and fatty acid composition of Pseudo-nitzschia multiseries and Pseudo-nitzschia pungens and effects of lipolytic enzyme deactivation. Phytochemistry 52:561-566

Cabezas-Pizarro J, Redondo-Solano M, Umana-Gamboa C, AriasEchandi ML (2018) Antimicrobial activity of different sodium and potassium salts of carboxylic acid against some common foodborne pathogens and spoilage-associated bacteria. Rev Argent Microbiol 50:56-61

Caldwell GS (2009) The influence of bioactive oxylipins from marine diatoms on invertebrate reproduction and development. Mar Drugs 7:367-400

Cequier-Sanchez E, Rodriguez C, Ravelo AG, Zarate R (2008) Dichloromethane as a solvent for lipid extraction and assessment of lipid classes and fatty acids from samples of different natures. J Agric Food Chem 56:4297-4303

Chen L, Liu TZ, Zhang W, Chen XL, Wang JF (2012) Biodiesel production from algae oil high in free fatty acids by two-step catalytic conversion. Bioresour Technol 111:208-214

Chen YC (2012) The biomass and total lipid content and composition of twelve species of marine diatoms cultured under various environments. Food Chem 131:211-219

Cuellar-Bermudez SP, Aguilar-Hernandez I, Cardenas-Chavez DL, Ornelas-Soto N, Romero-Ogawa MA, Parra-Saldivar R (2015) Extraction and purification of high-value metabolites from microalgae: essential lipids, astaxanthin and phycobiliproteins. Microb Biotechnol 8:190-209

Cutignano A, d'Ippolito G, Romano G, Lamari N, Cimino G, Febbraio F, Fontana A (2006) Chloroplastic glycolipids fuel aldehyde biosynthesis in the marine diatom Thalassiosira rotula. Chembiochem 7: 450-456

Cutignano A, Lamari N, d'Ippolito G, Manzo E, Cimino G, Fontana A (2011) Lipoxygenase products in marine diatoms: a concise analytical method to explore the functional potential of oxylipins. J Phycol $47: 233-243$
d'Ippolito G, Tucci S, Cutignano A, Romano G, Cimino G, Miralto A, Fontana A (2004) The role of complex lipids in the synthesis of bioactive aldehydes of the marine diatom Skeletonema costatum. Biochim Biophys Acta Mol Cell Biol Lipids 1686:100-107

Dunstan GA, Volkman JK, Barrett SM, Leroi JM, Jeffrey SW (1994) Essential polyunsaturated fatty-acids from 14 species of diatom (Bacillariophyceae). Phytochemistry 35:155-161

FAO (2020) The state of world fisheries and aquaculture 2020. Sustainability in action. FAO, Rome, p 244

Feller G, Gerday C (2003) Psychrophilic enzymes: hot topics in cold adaptation. Nat Rev Microbiol 1:200-208

Folch J, Lees M, Stanley GHS (1957) A simple method for the isolation and purification of total lipides from animal tissues. J Biol Chem 226:497-509

Fontana A, d'Ippolito G, Cutignano A, Miralto A, Ianora A, Romano G, Cimino G (2007) Chemistry of oxylipin pathways in marine diatoms. Pure Appl Chem 79:481-490

Gerecht A, Romano G, Ianora A, d'Ippolito G, Cutignano A, Fontana A (2011) Plasticity of oxylipin metabolism among clones of the marine diatom Skeletonema marinoi (Bacillariophyceae). J Phycol 47: 1050-1056

Heasman M, Diemar J, O'connor W, Sushames T, Foulkes L (2000) Development of extended shelf-life microalgae concentrate diets harvested by centrifugation for bivalve molluscs-a summary. Aquac Res 31:637-659

Hosseinizand H, Lim CJ, Webb E, Sokhansanj S (2017) Economic analysis of drying microalgae Chlorella in a conveyor belt dryer with recycled heat from a power plant. Appl Therm Eng 124:525-532

Jacobsen C, Timm M, Meyer AS (2001) Oxidation in fish oil enriched mayonnaise: ascorbic acid and low $\mathrm{pH}$ increase oxidative deterioration. J Agric Food Chem 49:3947-3956

Khozin-Goldberg I, Iskandarov U, Cohen Z (2011) LC-PUFA from photosynthetic microalgae: occurrence, biosynthesis, and prospects in biotechnology. Appl Microbiol Biotechnol 91:905-915

Kris-Etherton PM, Grieger JA, Etherton TD (2009) Dietary reference intakes for DHA and EPA. Prostaglandins Leukot Essent Fat Acids 81:99-104

Kuczynska P, Jemiola-Rzeminska M, Strzalka K (2015) Photosynthetic pigments in diatoms. Mar Drugs 13:5847-5881

Makhzoum A, Owusu RK, Knapp JS (1993) The conformational stability of a lipase from a psychrotrophic Pseudomonas fluorescens. Food Chem 46:355-359

Miyashita K, Takagi T (1986) Study on the oxidative rate and prooxidant activity of free fatty-acids. J Am Oil Chem Soc 63:1380-1384

Olsen RL, Toppe J (2017) Fish silage hydrolysates: not only a feed nutrient, but also a useful feed additive. Trends Food Sci Technol 66:93-97

Owusu RK, Makhzoum A, Knapp JS (1992) Heat inactivation of lipase from psychrotrophic Pseudomonas fluorescens p38 - activation parameters and enzyme stability at low or ultra-high temperatures. Food Chem 44:261-268

Ozyurt G, Ozkutuk AS, Ucar Y, Durmus M, Ozogul Y (2018) Fatty acid composition and oxidative stability of oils recovered from acid silage and bacterial fermentation of fish (sea bass - Dicentrarchus labrax) by-products. Int J Food Sci Technol 53:1255-1261

Pohnert G (2002) Phospholipase a(2) activity triggers the woundactivated chemical defense in the diatom Thalassiosira rotula. Plant Physiol 129:103-111

Ryckebosch E, Muylaert K, Eeckhout M, Ruyssen T, Foubert I (2011) Influence of drying and storage on lipid and carotenoid stability of the microalga Phaeodactylum tricornutum. J Agric Food Chem 59: 11063-11069

Safafar H, Langvad S, Moller P, Jacobsen C (2017) Storage conditions affect oxidative stability and nutritional composition of freeze-dried Nannochloropsis salina. Eur J Lipid Sci Technol 119:10 
Salem N, Eggersdorfer M (2015) Is the world supply of omega-3 fatty acids adequate for optimal human nutrition? Curr Opin Clin Nutr Metab Care 18:147-154

Seyhan F, Tijskens LMM, Evranuz O (2002) Modelling temperature and $\mathrm{pH}$ dependence of lipase and peroxidase activity in Turkish hazelnuts. J Food Eng 52:387-395

Shah MR, Lutzu GA, Alam A, Sarker P, Chowdhury MAK, Parsaeimehr A, Liang YM, Daroch M (2018) Microalgae in aquafeeds for a sustainable aquaculture industry. J Appl Phycol 30:197-213

Sprague M, Dick JR, Tocher DR (2016) Impact of sustainable feeds on omega-3 long-chain fatty acid levels in farmed Atlantic salmon, 2006-2015. Sci Rep 6:9

Stoffel W, Chu F, Ahrens EH (1959) Analysis of long-chain fatty acids by gas-liquid chromatography - micromethod for preparation of methyl esters. Anal Chem 31:307-308

Svenning JB, Dalheim L, Eilertsen HC, Vasskog T (2019) Temperature dependent growth rate, lipid content and fatty acid composition of the marine cold-water diatom Porosira glacialis. Algal Res 37:11-16

Tocher DR (2015) Omega-3 long-chain polyunsaturated fatty acids and aquaculture in perspective. Aquaculture 449:94-107
Uradnikova M (2020) Species validity of five common northern/Arctic spring bloom diatoms: a combined morphological and molecular study. UiT, the Arctic University of Norway,

Welladsen H, Kent M, Mangott A, Li Y (2014) Shelf-life assessment of microalgae concentrates: effect of cold preservation on microalgal nutrition profiles. Aquaculture 430:241-247

Wendt LM, Kinchin C, Wahlen BD, Davis R, Dempster TA, Gerken H (2019) Assessing the stability and techno-economic implications for wet storage of harvested microalgae to manage seasonal variability. Biotechnol Biofuels 12:14

Wichard T, Gerecht A, Boersma M, Poulet SA, Wiltshire K, Pohnert G (2007) Lipid and fatty acid composition of diatoms revisited: rapid wound-activated change of food quality parameters influences herbivorous copepod reproductive success. Chembiochem 8:11461153

Publisher's note Springer Nature remains neutral with regard to jurisdictional claims in published maps and institutional affiliations. 